\title{
THE EFFICIENCY OF MICROBIAL PREPARATIONS AT SUGAR SORGHUM CULTIVATION IN POLISSYA REGION
}

\author{
Gorbachenko N. I.
}

Institute of Agricultural Microbiology and Agroindustrial production NAAS, 97, Shevchenko str., Chernihiv, 14027, Ukraine

The paper presents the results of lyzimetric and field studies on the impact of microbial preparations Microhumin and Polymyxobacteryn combined with mineral fertilizers on the productivity of sugar sorghum in Polissya region. It was shown that the pre-sowing seeds bacterization had increase crops yields by $5-9 \%$ and increased output of ethanol by 0.3 t/ha. Application of biological preparations had ensured less reduction of water-soluble humic substances by $28-32 \%$, nitrogen (nitrate) - by $11-$ 15\%, calcium - by 7\%, magnesium - by $8-15 \%$.

Keywords: microbial preparations, sugar sorghum, bioethanol, lizymetr.

Nowadays, a growing shortage of petroleum products, their high costs and environmental degradation encourage the search for alternative sources of clean energy. The use plants accumulated energy as a result of photosynthetic activity in the form of bioethanol is highly perspective. Global amounts of its production during the last decade have increased more than in three times. Bioethanol is used mainly as fuel mixtures to increase its octane number. Addition of $10 \%$ ethanol to the gasoline allows to reduce aerosolic emissions by $50 \%$ and emissions of carbon monoxide (CO) by $30 \%$

According to the Law of Ukraine "About alternative fuel" with amendments from 19.06.12 the gradual increase in the proportion of regulatory specified production and use of biofuels and blended fuels is anticipated. Since 2014, the 5\% share of ethanol in gasoline is mandatory and should rise to $7 \%$ in 2016 . In order to implement the provisions of this Law, taking into the account the internal use of gasoline at the level of 4.5 million tons per year the annual production of bioethanol should be over 300 thousand tons. In this regard, the search of promising raw material for its production is important.

A valuable source of raw materials for bioethanol production is sugar crops (sugar beet, sugar sorghum, chicory, etc.). The most effective sugar crop for Ukraine for ethanol production is sugar beets. More than 5 thousand liters of bioethanol can be received from 1 hectare of sugar beets. Sugar sorghum is also effective and promising crop in the Ukraine. $90-100 \mathrm{t} / \mathrm{ha}$ of biomass of sugar sorghum can be harvested from 1 hectare with sugar content of the juice up to $20 \%$.

Soil and climatic conditions in Ukraine is quite favorable for growing of sugar sorghum [1, 2]. Nevertheless, the farming techniques and growing technology for energy production from plants biomass, despite the prospects are still at the early stage of their development [3]. Taking into the account the great impact of microbial 
preparations on optimization of root nutrition conditions, plant growth and development [4, 5], we have oriented our research towards the development of agroecological bases of cultivation technology of sugar sorghum and use of microbial preparations in Polissia region for the bioethanol production.

Materials and methods. The studies were performed in stationary lyzimetric conditions and in field experiments in the Institute of Agricultural Microbiology and agroindustrial production NAAS during 2011 - 2013. Area of lyzimeter cells is 3.8 $\mathrm{m}^{2}$, area of field plots $-40 \mathrm{~m}^{2}$. Threefold experiments repetition was used. Seeding rate of sorghum -300 thousands / ha. Harvesting was performed during three stages tasseling (at maximum regrowth), wax ripeness and full ripeness.

Lysimeter experiments were performed on sod-podzolic sandy loam soils with the following agrochemical characteristics of the arable layer: humus (by Tyurin) $1.1 \%, \mathrm{pH} 5.0$, hydrolytic acidity (by Kappen) $-2.5 \mathrm{mEq} .100 \mathrm{~g}$, P2O5 content (by Kirsanov) - $17.0 \mathrm{mg}$ per $100 \mathrm{~g}$, K2O (by Maslov) - $6.2 \mathrm{mg}$ per $100 \mathrm{~g}$ soil. Agrochemical characteristics of arable soil and subsoil layers on experimental plots in field experiment are shown in Table 1.

Table 1. Agrochemical characteristics of meadow gley sandy soil

\begin{tabular}{|l|l|l|}
\hline \multirow{2}{*}{ Index } & Soil layer, cm \\
\cline { 2 - 3 } & $0-20$ & $20-40$ \\
\hline Humus, \% & 3,2 & 2,7 \\
\hline $\begin{array}{l}\text { Easily hydrolysable nitrogen, mg per 100 g of soil } \\
\text { (at experiment lay out) }\end{array}$ & 6,3 & 3,1 \\
\hline Mobile phosphorous, mg $\mathrm{P}_{2} \mathrm{O}_{5}$ per $100 \mathrm{~g}$ of soil & 6,9 & 6,7 \\
\hline Exchangeable potassium, mg $\mathrm{K}_{2} \mathrm{O}$ per 100 of soil & 7,0 & 3,2 \\
\hline pH (salt) & 6,9 & 6,6 \\
\hline Sum of absorbed bases, mg-eqv. per $100 \mathrm{~g}$ of soil & 6,4 & 5,1 \\
\hline Hydrolytic acidity, mg-eqv. per $100 \mathrm{~g}$ of soil & 1,3 & 1,5 \\
\hline
\end{tabular}

Pre-sowing bacterization of sorghum seeds was carried out in accordance with the recommendations of the preparations manufacturer [6].

Microhumin - complex preparation, includes bacterial components (Azospirillum bacteria) and vermicompost extract containing the physiologically active substance (TU 24.1-00497360-007:2009). It increases the activity of associative nitrogen fixation, facilitates the phosphorous mobilization in soil, stimulates growth and development of plants. Microhumin is used for pre-sowing seeds inoculation or planting material.

Polymyxobacteryn - microbial preparation with Paenibacillus polymyxa KB (TU 24.1-00497360-004:2009). Biological agent of the preparation produces complex naturally occurring growth regulators, organic acids and phosphatase that promotes dissolution of hardly soluble mineral and organic phosphates in soil. 
The study was conducted as on the following scheme:

1. $\mathrm{N}_{90} \mathrm{P}_{90} \mathrm{~K}_{90}$ (control);

2. $\mathrm{N}_{70} \mathrm{P}_{90} \mathrm{~K}_{90}+$ Microhumin

3. $\mathrm{N}_{90} \mathrm{P}_{70} \mathrm{~K}_{90}+$ Polymyxobacteryn.

Reduction of mineral nitrogen does was performed in variant with Microhumin (from 90 to $70 \mathrm{~kg} / \mathrm{ha}$ ). In variant with Polymyxobacteryn application the dose of phosphorus was reduced from 90 to $70 \mathrm{~kg} / \mathrm{ha}$, stipulated by the equivalence of microbial preparations impact to the certain quantities of these nutrients [5].

In lyzimeter experiment, in addition to the options stated above two more options were included to the experimental design - fallow and grasses in order to compare the runoff intensity options. That was used to study water regime type and losses of nutrients and humic substances beyond the root zone. The filtrate was analyzed by conventional method of Arinushkinf E.N. [7]. Agrochemical soil analysis was performed using Peterburskiy A.V. methods [8].

The assimilation surface area of plants and crop productivity were determined in field experiment [9]. Harvest accounting method - continuous per each plot, experimental data was processed using the variance analysis method [10].

Results and discussion. As the result of lyzimeter research the degree of nutrients migration from soil water runoff beyond the root zone of soil. The periodical wash-type water regime was studied during the study period. Infiltration was observed during the autumn-winter and spring-summer periods. For sugar sorghum plants infiltration was higher relatively to the fallow grasses by $15.2-7.7$ $\mathrm{mm}$ and lower by $10.6-3.1 \mathrm{~mm}$ comparing to the black fallow. Nutrients were also washed with the moisture beyond the root layer of sugar sorghum plant (Table 2).

It was shown that biological preparations had ensured reduction of humic substances losses on $28-32 \%, 11-15 \%$ of nitrates, calcium $-7 \%$, magnesium $-8-$ $15 \%$, which indicates the feasibility of decreasing at the sod-podzolic type of soils the dose of active ingredient of nitrogen and phosphate fertilizers $(20-30 \mathrm{~kg} / \mathrm{ha})$ under the application of biological preparations.

Reduction of nutrients leaching intensity is possibly associated with the increased rate of their removal with harvest and temporary bounding with increased root system of bacteryzed plants which was had previously been shown in our research studies.

Determination of plants assimilation surface in field experiments in dynamics had shown its increase under the influence of microbial preparations (Table 3).

Seeds treatment with microbial preparations ensures the increase of leaves surface area on $1.3-2.2$ thousand $\mathrm{m}^{2}$. The highest rate of net photosynthesis productivity of $3.59 \mathrm{~g} / \mathrm{m} 2$ / day of sugar sorghum plants was observed in the variant with pre-sowing seeds treatment with Polymyxobacteryn. The highest photosynthetic potential 3.25 (million $\left.\mathrm{m}^{2} / \mathrm{ha}\right) \mathrm{x}$ days was also observed in the variant with Polymyxobacteryn. 
Table 2. Loss of humic substances and nutrients at sugar sorghum crops depending on various fertilization systems, $\mathrm{kg} / \mathrm{ha}$

\begin{tabular}{|l|l|l|l|l|l|l|l|}
\hline Variants & $\begin{array}{l}\text { Moisture, } \\
\text { MM }\end{array}$ & $\begin{array}{l}\text { Water } \\
\text { soluble } \\
\text { humus }\end{array}$ & $\mathrm{NO}_{3}$ & $\mathrm{P}_{2} \mathrm{O}_{5}$ & $\mathrm{~K}_{2} \mathrm{O}$ & $\mathrm{CaO}$ & $\mathrm{MgO}$ \\
\hline Black fallow & 56,1 & 10,3 & 89,2 & 20,5 & 4,2 & 26,4 & 14,2 \\
\hline Grass fallow & 37,8 & 6,7 & 0,9 & 0,9 & 1,9 & 45,7 & 10,9 \\
\hline $\mathrm{N}_{90} \mathrm{P}_{90} \mathrm{~K}_{90}-$ control & 48,4 & 24,1 & 36,0 & 6,1 & 7,1 & 64,3 & 22,4 \\
\hline $\begin{array}{l}\mathrm{N}_{70} \mathrm{P}_{90} \mathrm{~K}_{90}+ \\
\text { Microhumin }\end{array}$ & 41,6 & 18,8 & 31,2 & 6,0 & 5,2 & 60,0 & 20,8 \\
\hline $\begin{array}{l}\mathrm{N}_{90} \mathrm{P}_{70} \mathrm{~K}_{90}+ \\
\text { Polymyxobacteryn }\end{array}$ & 40,9 & 18,2 & 32,5 & 6,0 & 6,0 & 59,2 & 19,4 \\
\hline
\end{tabular}

Table 3. Photosynthetic activity of sugar sorghum plants depending on various fertilization systems

\begin{tabular}{|l|l|l|l|l|}
\hline Variants & $\begin{array}{l}\text { Leaf } \\
\text { surface } \\
\text { area, thsnd } \\
\mathrm{m}^{2} / \mathrm{ha}\end{array}$ & $\begin{array}{l}\text { Pure } \\
\text { photosynthetic } \\
\text { productivity, } \\
\mathrm{g} / \mathrm{m}^{2} \text { per day }\end{array}$ & $\begin{array}{l}\text { Photosynthetic } \\
\text { potential, }(\mathrm{mln} \\
\mathrm{m}^{2} / \text { ha) x days }\end{array}$ & $\begin{array}{l}\text { Тривалість } \\
\text { вегетаційного } \\
\text { періоду, днів }\end{array}$ \\
\hline $\mathrm{N}_{90} \mathrm{P}_{90} \mathrm{~K}_{90}-$ control & 50,93 & 3,48 & 4,07 & 139 \\
\hline $\begin{array}{l}\mathrm{N}_{70} \mathrm{P}_{90} \mathrm{~K}_{90}+ \\
\text { Microhumin }\end{array}$ & 52,23 & 3,27 & 3,25 & 138 \\
\hline $\begin{array}{l}\mathrm{N}_{90} \mathrm{P}_{70} \mathrm{~K}_{90}+ \\
\text { Polymyxobacteryn }\end{array}$ & 53,13 & 3,52 & 3,58 & 141 \\
\hline
\end{tabular}

According to the research data the biomass growth had continued till the wax ripeness stage of sugar sorghum plants. The use of biological preparations had ensured additional $5.3-6.2 \mathrm{t} / \mathrm{ha}$ of biomass, or $5.8 \%$ increase compared to the control values (on $\mathrm{N}_{90} \mathrm{P}_{90} \mathrm{~K}_{90}$ background) (Table 4).

Data shown in table 5 indicates that dry matter of sugar sorghum had increased throughout the growing season. The highest yield of dry matter at biomass harvesting was obtained in the phase of full ripeness - from 12.6 to $13.9 \mathrm{t} / \mathrm{ha}$. The impact of studied preparations on dry matter accumulation was similar to the biomass yield values.

Sugar content in above ground mass while crop maturing had increased and depended on the harvesting terms and was highest at full ripeness stage (Table 6). The reduction of sugar content in the biomass of inoculated plants during the first studied stage and its subsequent increase during the next stages of crop ripening was observed. The maximum sugar content was obtained during the biomass harvesting in the phase of full plants ripeness. 
Table 4. Biomass yield of sugar sorghum plants under the influence of microbial preparations, $t / h a$

\begin{tabular}{|l|l|l|l|l|l|l|}
\hline \multirow{2}{*}{ Variants } & \multicolumn{3}{|l|}{ Harvesting terms } \\
\cline { 2 - 8 } & \multicolumn{2}{|l|}{$\begin{array}{l}\text { Tasseling }+ \\
\text { regrowth }\end{array}$} & \multicolumn{2}{l|}{ Wax ripeness } & \multicolumn{2}{l|}{ Full ripeness } \\
\cline { 2 - 8 } & t/ha & $\begin{array}{l}\text { increm } \\
\text { ent, } \%\end{array}$ & t/ha & $\begin{array}{l}\text { increme } \\
\text { nt, } \%\end{array}$ & t/ha & $\begin{array}{l}\text { increme } \\
\text { nt, \% }\end{array}$ \\
\hline $\mathrm{N}_{90} \mathrm{P}_{90} \mathrm{~K}_{90}-$ control & 74,3 & - & 64,4 & - & 64,7 & - \\
\hline $\mathrm{N}_{70} \mathrm{P}_{90} \mathrm{~K}_{90}+$ Microhumin & 78,3 & 5 & 69,8 & 8 & 70,0 & 8 \\
\hline $\begin{array}{l}\mathrm{N}_{90} \mathrm{P}_{70} \mathrm{~K}_{90}+ \\
\text { Polymyxobacteryn }\end{array}$ & 78,8 & 6 & 67,6 & 5 & 67,7 & 5 \\
\hline LSD $_{05}$ & 2,7 & & 2,8 & & 3,0 & \\
\hline
\end{tabular}

Table 5. Dry matter yield of sugar sorghum depending on harvesting terms, t/ha

\begin{tabular}{|c|c|c|c|c|c|c|}
\hline \multirow{3}{*}{ Variants } & \multicolumn{6}{|c|}{ Harvesting terms } \\
\hline & \multicolumn{2}{|c|}{$\begin{array}{l}\text { Tasseling + } \\
\text { regrowth }\end{array}$} & \multicolumn{2}{|c|}{ Wax ripeness } & \multicolumn{2}{|c|}{ Full ripeness } \\
\hline & t/ha & $\begin{array}{l}\text { increme } \\
\text { nt, } \%\end{array}$ & $\mathrm{t} / \mathrm{ha}$ & $\mathrm{t} / \mathrm{ha}$ & $\begin{array}{l}\text { incre } \\
\text { ment, } \\
\%\end{array}$ & $\mathrm{t} / \mathrm{ha}$ \\
\hline $\mathrm{N}_{90} \mathrm{P}_{90} \mathrm{~K}_{90}-$ control & 14,1 & - & 12,4 & - & 12,6 & - \\
\hline $\mathrm{N}_{70} \mathrm{P}_{90} \mathrm{~K}_{90}+$ Microhumin & 15,0 & 6 & 13,4 & 8 & 13,7 & 9 \\
\hline $\begin{array}{l}\mathrm{N}_{90} \mathrm{P}_{70} \mathrm{~K}_{90}+ \\
\text { Polymyxobacteryn }\end{array}$ & 15,4 & 9 & 13,1 & 6 & 13,2 & 5 \\
\hline $\mathrm{LSD}_{05}$ & \multicolumn{2}{|l|}{0,5} & \multicolumn{2}{|l|}{0,9} & \multicolumn{2}{|l|}{1,3} \\
\hline
\end{tabular}

Table 6. The sugar content in the stems of sugar sorghum depending on the harvesting terms and action of biological preparations

\begin{tabular}{|c|c|c|c|c|c|c|}
\hline \multirow{3}{*}{ Variants } & \multicolumn{6}{|c|}{ Harvesting terms } \\
\hline & \multicolumn{2}{|c|}{$\begin{array}{l}\text { Tasseling + } \\
\text { regrowth }\end{array}$} & \multicolumn{2}{|c|}{ Wax ripeness } & \multicolumn{2}{|c|}{ Full ripeness } \\
\hline & $\begin{array}{l}\text { Sugar } \\
\text { conten } \\
\text { t, } \%\end{array}$ & $\begin{array}{l}\text { Sugar } \\
\text { harvest } \\
\text {, } / \text { ha }\end{array}$ & $\begin{array}{l}\text { Sugar } \\
\text { conten } \\
\text { t, \% }\end{array}$ & $\begin{array}{l}\text { Sugar } \\
\text { harvest } \\
\text {, } / \text { ha }\end{array}$ & $\begin{array}{l}\text { Sugar } \\
\text { conten } \\
\text { t, } \%\end{array}$ & $\begin{array}{l}\text { Sugar } \\
\text { harves } \\
\mathrm{t}, \mathrm{t} / \mathrm{ha}\end{array}$ \\
\hline $\mathrm{N}_{90} \mathrm{P}_{90} \mathrm{~K}_{90}-$ control & 14,0 & 5,32 & 16,02 & 5,15 & 17,07 & 5,55 \\
\hline $\mathrm{N}_{70} \mathrm{P}_{90} \mathrm{~K}_{90}+$ Microhumin & 14,5 & 5,11 & 16,08 & 5,61 & 17,12 & 6,11 \\
\hline $\begin{array}{l}\mathrm{N}_{90} \mathrm{P}_{70} \mathrm{~K}_{90}+ \\
\text { Polymyxobacteryn }\end{array}$ & 14.5 & 5,14 & 16,10 & 5,44 & 17,17 & 5,98 \\
\hline $\mathrm{LSD}_{05}$ & \multicolumn{2}{|l|}{0,40} & \multicolumn{2}{|l|}{0,46} & \multicolumn{2}{|l|}{0,65} \\
\hline
\end{tabular}


Higher bioethanol yield was obtained at sugar sorghum harvesting in the full ripeness stage and was within the $4.2 \mathrm{t} / \mathrm{ha}-4.5 \mathrm{t} / \mathrm{ha}$ range (Table 7 ).

\section{Table 7. Bioethanol output from sugar sorghum juice depending on the harvesting terms and action of biological preparations}

\begin{tabular}{|l|l|l|l|l|l|l|}
\hline \multirow{2}{*}{ Variants } & \multicolumn{4}{|l}{ Harvesting terms } \\
\cline { 2 - 8 } & $\begin{array}{l}\text { Tasseling }+ \\
\text { regrowth }\end{array}$ & \multicolumn{2}{ll}{$\begin{array}{l}\text { Tasseling }+ \\
\text { regrowth }\end{array}$} & \multicolumn{2}{l}{$\begin{array}{l}\text { Tasseling }+ \\
\text { regrowth }\end{array}$} \\
\cline { 2 - 8 } & $\begin{array}{l}\text { Bioethanol } \\
\text { output }\end{array}$ & \multicolumn{2}{l}{$\begin{array}{l}\text { Bioethanol } \\
\text { output }\end{array}$} & \multicolumn{2}{l}{$\begin{array}{l}\text { Bioethanol } \\
\text { output }\end{array}$} \\
\cline { 2 - 8 } & $\mathrm{kg} / \mathrm{t}$ & $\mathrm{t} / \mathrm{ha}$ & $\mathrm{kg} / \mathrm{t}$ & $\mathrm{t} / \mathrm{ha}$ & $\mathrm{kg} / \mathrm{t}$ & $\mathrm{t} / \mathrm{ha}$ \\
\hline $\mathrm{N}_{90} \mathrm{P}_{90} \mathrm{~K}_{90}-$ control & 115 & 3,8 & 128 & 4,1 & 129 & 4,2 \\
\hline $\begin{array}{l}\mathrm{N}_{70} \mathrm{P}_{90} \mathrm{~K}_{90}+ \\
\text { Microhumin }\end{array}$ & 117 & 4,1 & 129 & 4,5 & 129 & 4,5 \\
\hline $\begin{array}{l}\mathrm{N}_{90} \mathrm{P}_{70} \mathrm{~K}_{90}+ \\
\text { Polymyxobacteryn }\end{array}$ & 117 & 4,2 & 129 & 4,4 & 129 & 4,5 \\
\hline
\end{tabular}

Seeds treatment with microbial preparations had ensured bioethanol output increase by $0.3 \mathrm{t} / \mathrm{ha}$.

Summary analysis of the economic and energy efficiency of the use of microbial preparations in cultivation technology of sugar sorghum it was determined that the use of biological preparations had improved economic and energy performance of sorghum production (Table 8).

It was established that the technology costs are increased slightly by 88.4 $\mathrm{UAH} / \mathrm{ha}$ at use of biopreparations, which at first place is associated with biomass accumulation. However, the effect of advanced cultivation technology per unit was 19.1 UAH/t.

Using advanced technology increases crop profitability by $31 \%$, profit - by 2191.6 UAH/ha and energy efficiency ratio - by 3.5 units.

Consequently, the studies performed had demonstrated the feasibility of microbial preparations Microhumin and Polymyxobacteryn at cultivation of sugar sorghum in Polissya region for the bioethanol production. The use of mineral fertilizers combined with the application of microbial preparations had provided the highest effect and enhanced use of nutrients, particularly nitrogen and phosphorus, from the soil. It has been proved that at seeds inoculation with Polymyxobacteryn the assimilation system of plants had the highest photosynthetic activity -3.58 (mln. $\mathrm{m}^{2} / \mathrm{ha}$ ) $\mathrm{x}$ days, which is $16 \%$ more than in control. Filtration mode under the sugar sorghum plants was higher as compared to the fallow grasses and lower in comparison to the black fallow. Biological preparations had reduced losses of humic 
substances by $28-32 \%$, nitrogen (nitrate) - by $15-11 \%$, calcium - by $7 \%$, magnesium - by $8-15 \%$, which indicates the feasibility of nitrogen and phosphate fertilizer dose reduction by $20-30 \mathrm{~kg}$ of active ingredient under the use of biological preparations.

Table 8. Economic and energy efficiency of growing sugar sorghum for bioethanol production under the different fertilization systems

\begin{tabular}{|c|c|c|c|}
\hline \multirow[t]{2}{*}{ Indices } & \multicolumn{2}{|c|}{ Technology } & \multirow{2}{*}{$\begin{array}{l}\text { Improvement } \\
\text { effect, } \pm\end{array}$} \\
\hline & Existent & Advanced & \\
\hline Biomass yield, $\mathrm{t} / \mathrm{ha}$ & 64,7 & 79,9 & 15,2 \\
\hline Juice sugar content, $\%$ & 16,1 & 17,3 & 1,2 \\
\hline Bioethanol output, t/ha & 3,8 & 4,6 & 0,8 \\
\hline Dry matter output, $\mathrm{t} / \mathrm{ha}$ & 14,1 & 17,4 & 3,3 \\
\hline $\begin{array}{l}\text { Production costs: } \\
\text { per area unit, UAH/ha } \\
\text { per output unit. UAH/t }\end{array}$ & $\begin{array}{l}6885,8 \\
106,4\end{array}$ & $\begin{array}{l}6974,2 \\
87.3\end{array}$ & $\begin{array}{l}-88,4 \\
19,1\end{array}$ \\
\hline Income from output sales, UAH/ha & 9705 & 11985 & 2190 \\
\hline Profit, UAH/ha & 2819,2 & 5010,8 & 2191,6 \\
\hline Profitability, \% & 40,9 & 71,8 & 30,9 \\
\hline Energy output, GJ/ha & 307,4 & 379,3 & 71,9 \\
\hline $\begin{array}{l}\text { Energy costs: } \\
\text { per area unit, GJ/ha } \\
\text { per output unit, GJ/t }\end{array}$ & $\begin{array}{l}15,8 \\
0,24\end{array}$ & $\begin{array}{l}16,5 \\
0,21\end{array}$ & $\begin{array}{l}0,7 \\
0,03\end{array}$ \\
\hline Energy efficiency ratio & 19,5 & 23,0 & 3,5 \\
\hline
\end{tabular}

